\title{
Mortal Knowledge: Akrasia in English Renaissance Tragedy
}

\author{
Emily Vasiliauskas
}

If to do were as easy as to know what were good to do, chapels had been churches and poor men's cottages princes' palaces. ${ }^{1}$

\section{Akrasia in Ancient Greek Ethics and Poetics: Knowing and Doing}

Is it possible to perform an action in the full knowledge that it would be wrong to do so? This may seem like a strange question with which to open an essay on the tragedy of early modern England, which produced such exuberant evildoers as Richard III, Sejanus, and the Cardinal from John Webster's The Duchess of Malfi. Evidently, purposeful criminality was not only a logical possibility, but also a dramatic resource in a period that made ambition and revenge its abiding tragic motives. But the relationship between knowledge and wrongdoing was a serious problem within ancient Greek philosophy, and Aristotle's treatment of tragedy's aesthetic norms derives in part from his understanding of the crux. In this essay, I will show how akrasia - 'the state of tending to act against one's better judgment' - a concept which Aristotle identified as un-tragic and whose very existence Socrates denied, became indispensable to English Renaissance tragedy, a genre designation which I apply to both dramatic and poetic narratives. $^{2}$ I will examine the consequences of this transformation for tragedy's account of the human will, its narrative form, and its purpose within a political community. Whereas Aristotelian tragedies link a momentary action in the

1 William Shakespeare, The Merchant of Venice, ed. M.M. Mahood (Cambridge: Cambridge University Press, 1987) The New Cambridge Shakespeare, 2.1.11-12.

2 OED Online, s.v. 'akrasia', accessed November 24, 2014, http://www.oed.com/view/Entry/ 240257 . 
past with a permanent condition of abjection, akratic tragedies feature protagonists who purposefully commit themselves to evil for the medium term, often in the expectation that they will ultimately forsake it. A strange passage in the history of evil, when it became more closely allied with behavior than with identity: these early modern dramas depict wrongdoing as capable of being forgiven and redeemed, but also as undertaken knowingly, strategically, even dutifully.

In Plato's Protagoras, Socrates makes a case for the unity of virtue. Not only are the various species of goodness-wisdom, temperance, courage, justice, and holiness - ultimately indistinguishable from one another, but goodness is also identical to pleasure, evil identical to pain. By establishing this synthesis, Socrates is able to undermine his interlocutor's intuitively sensible claim, namely, that those who act as they know they shouldn't do so because they are tempted by pleasure:

Let us lay it down as our statement, that a man does evil in spite of knowing the evil of it. Now if someone asks us: Why? we shall answer: Because he is overcome. By what? the questioner will ask us; and this time we shall be unable to reply: By pleasure - for this has exchanged its name for 'the good.' So we must answer only with the words: Because he is overcome. By what? says the questioner. The good-must surely be our reply. ${ }^{3}$

Here akrasia becomes a simple contradiction in terms-a man does evil in spite of knowing the evil of it because he is overcome by the good—and what initially seems to be an issue of moral weakness is recast as a defect in knowledge. As long as an agent can accurately measure quantities of pleasure and pain, he will always act so as to maximize goodness and minimize evil. Socrates, anticipating utilitarianism and the rise of homo economicus, concludes that no one can act against her better judgment, because no one will act knowingly against her own interests.

Aristotle takes an analytic rather than a synthetic approach to virtue in The Nicomachean Ethics. As a result, he provides a more nuanced account of the possible motivations for evil action, an account which makes room for both emotions, which are missing from Socrates' discussion of akrasia, and different degrees of knowledge. Particularly important for Aristotle is the power that certain emotions can exert, not over the existence of knowledge, but rather over the availability of knowledge within the mind:

3 Plato, Protagoras, $355^{\mathrm{B}-\mathrm{C}}$ (transl. W.R.M. Lamb). 
for it is evident that anger, sexual desire, and certain other passions, actually alter the state of the body, and in some cases even cause madness. It is clear therefore that we must pronounce the unrestrained to have knowledge' only in the same way as men who are asleep or drunk [...]. Persons in the states mentioned repeat propositions of geometry and verses of Empedocles; students who have just begun a subject reel off its formulae, though they do not yet know their meaning, for knowledge has to become part of the tissue of the mind, and this takes time. ${ }^{4}$

Knowledge does not always exercise mastery over action, because consciousness can be suspended in waking life, as well as during sleep. Aristotle portrays people who are alienated from their own knowledge as imperfect or incomplete - they are compared to madmen and children — and yet utterly ordinary - their defects are shared by all, at least some of the time. At no point in his taxonomy of self-restraint, unrestraint, temperance, and profligacy, however, does he dispute the core of Socrates' claim that full and available knowledge of evil is incompatible with its enactment. Instead, The Nicomachean Ethics describes the conditions that can disrupt the elegant circuit uniting cognition, virtue, and action, conditions which serve to mitigate wrongdoing by associating it with temporary or otherwise partial ignorance.

The word akrasia does not appear in the Poetics, but the concept informs Aristotle's definition of the best kind of tragedy. His ideal plot features a protagonist of intermediate moral standing - 'someone not preeminent in virtue and justice' who is nevertheless basically good — falling into adversity because of an error (hamartia). ${ }^{5}$ The error should not involve evil, which would compromise the protagonist's fundamental goodness and, therefore, his ability to inspire pity and fear among spectators of the action. Relevant here is Aristotle's conflation of morality and class status in his categorization of epic and tragedy, on the one hand, and satire and comedy, on the other: 'the more serious produced mimesis of noble actions and the actions of noble people, while the more vulgar depicted the actions of the base. ${ }^{6}$ Although the Poetics does not explicate the difference between mistakenness on the one hand and full-blown depravity on the other, it is knowledge that seems to mark the boundary between the two in the examples offered for analysis. Aristotle deplores tragedies in which 'the agents act in knowledge and cognizance (as Euripides [...] made Medea

\footnotetext{
4 Aristotle, The Nicomachean Ethics, 7.3.7-8, 1147A (transl. H. Rackham).

5 Aristotle, Poetics, ch. 13, 1453A (transl. Stephen Halliwell).

6 Aristotle, Poetics, ch. 4, 1448B.
} 
kill her children)', tragedies, that is, in which akrasia plays a central role. ${ }^{7}$ To act knowingly in a tragedy is to veer away from error and toward evil; such an action, while of interest to some practitioners of the genre, does not for Aristotle conform to its highest standards. Better are plots in which the protagonist errs in ignorance only to be awakened into a recognition (anagnorisis) of the true nature of his action: Oedipus comes to understand the meaning of his mistakes long after he has already made them. This Sophoclean pattern of delayed understanding culminates in an excessive punishment of the protagonist: 'in his tragedies suffering is likely to be either disproportionate to its cause or totally undeserved. ${ }^{8}$ Just as in The Nicomachean Ethics, impediments to knowledge are necessary in the Poetics in order to attenuate an agent's relationship to his own wrongdoing. The closer a protagonist like Oedipus comes to acting out of ignorance, the less damage is done to his reputation with the audience and the more inexplicable is his pain: evidence that human effort is no match for human helplessness. The closer a protagonist like Medea comes to authentically akratic action, the further she departs from the narrative conventions that establish the moral function of tragedy within a political community.

Because ignorance limits the ability of an agent to intend or consent to an action, modern scholars have examined ancient Greek tragedy and philosophy for evidence of free will. To what extent does the moral quality of an action depend on an agent's power to choose? According to Kathy Eden, Aristotle's preferred form of tragic action is neither purposefully elected by the protagonist nor completely inadvertent: 'while it [hamartia] is not, strictly speaking, voluntary, in that the agent does not freely choose the act with full knowledge of its particulars, neither is it, strictly speaking, involuntary, in that it is not wholly unforeseen.'9 Although Jean-Pierre Vernant is probably right to contend that no formal category of the will is implied by Aristotle's discussion of the kind of ignorance which at once causes and excuses error, it is nevertheless clear that the normative tragic protagonist experiences at least the desire to have chosen differently, the will for a will. ${ }^{10}$ No such flicker of voluntariness appears in the

$7 \quad$ Aristotle, Poetics, ch. 14, 1453в.

8 Helen North, Sophrosyne: Self-Knowledge and Self-Restraint in Greek Literature (Ithaca: Cornell University Press, 1966) Cornell Studies in Classical Philology, 35, p. 50.

9 Kathy Eden, 'Poetics: A Defense of Tragic Fiction', in Rebecca Bushnell (ed.), A Companion to Tragedy (Malden, MA: Blackwell Publishing, 2005), pp. 41-50, esp. p. 46.

10 Jean-Pierre Vernant, 'Intimations of the Will in Greek Tragedy', in Jean-Pierre Vernant and Pierre Vidal-Naquet, Myth and Tragedy in Ancient Greece, transl. Janet Lloyd (New York: Zone, 1990), pp. 49-84, esp. p. 65. The most important contribution of Vernant's essay is to show that the divine necessity of tragic action is not incompatible with the 
Socratic discussion of akrasia, where the unity of virtue makes the will utterly superfluous: there is no process of choosing goodness that can be separated from the fact of knowing pleasure. Yet whether the will is absent or insignificant, ancient Greek philosophy consistently prefers to explain evil in terms of barriers to cognition rather than in terms of the subject's ability to exercise free choice.

Helene P. Foley and Jean E. Howard have recently argued that any reading of English Renaissance tragedy must be based on an understanding of its historical and social conditions, assembling a list of the many ways in which Shakespeare and his contemporaries departed from the conventions of ancient tragedy:

These dramatists knew Seneca, but they imitated him with great freedom and put his closet drama onto the stage [...], and they hardly knew Greek theater at all. Very few early modern tragedies had a chorus, actors did not use masks, and plays were not produced in competitive festivals; rather, after 1576 tragedies in England were overwhelmingly produced for a commercial stage, employed a supple blank verse and vigorous prose, sometimes contained clowns, featured multiple actions if not multiple plots, and used boy actors to play women's parts. ${ }^{11}$

It would seem that akrasia and the will belong on this list. These concepts are either excluded from or marginalized within Aristotle's Poetics, but they become crucial to the psychology of tragic action in early modern England: a rupture within a literary tradition that both reflects and contributes to a rupture within a broader understanding of human nature. Nevertheless, a remarkable feature of this innovation is the way in which it explicitly returns to ancient sources, not only in order to criticize them, but also in order to locate an alternative form of classicism. Try as he might, Aristotle could not eliminate Medea from his account of tragedy, and English writers would look to her as a model for their own experiments with akrasia.

personal responsibility of the protagonist: 'The sacrifice of Iphigenia is certainly necessary by reason of the situation that presses upon the king like fatality, but, at the same time, this murder is not only accepted but passionately desired by Agamemnon who is therefore responsible for it' (p. 72).

11 Helene P. Foley and Jean E. Howard, 'Introduction: The Urgency of Tragedy Now', PMLA 129 (2014), pp. 623-624. 


\section{Spenserian Akrasia: Temperance and Temporality in Tragic Narrative}

Whereas Aristotle portrays akrasia as a threat to the generic integrity of tragedy, English Renaissance writers identify it as a primary cause of tragic outcomes. When these protagonists embark upon evil, they tend to consent- knowingly and willfully - to temptation. Although the evil to which they consent can take the form of action (as in the murders of Duncan and Banquo in Macbeth), it can also take the form of behavior. In the latter case, protagonists succumb to a condition such as lust or greed, from which redemption seems to be tantalizingly possible. The tragic climax occurs as the suspense over whether the protagonist will change his life resolves in favor of his irredeemability. A choice that seems at first to involve only a temporary lapse proves to be permanent.

That Book II of Edmund Spenser's The Faerie Queene engages with a tragic mode of narration is evident from its opening canto. It begins with an episode that resembles the final scene in a gruesome drama of betrayal. Guyon, the knight of temperance, encounters a woman named Amavia at the edge of a forest. Badly hurt, she has just finished a virtuosic speech in which she welcomes death, when he manages to remove the blade from her wound and to bring her temporarily back to life. Asked how she came to be in such a state, she explains that Mortdant, her lover, went off in search of chivalric adventures, leaving her alone during her pregnancy. He became entangled with the aptly-named Acrasia, 'a false enchaunteresse, | That many errant knightes hath fowle fordonne.'12 Amavia went searching for him, giving birth to a son in the middle of her journey, and eventually discovered Mortdant in the Bower of Bliss, subjected both to his own lust and to Acrasia's pleasure:

Him so I sought, and so at last I fownd Where him that witch had thralled to her will, In chaines of lust and lewde desyres ybownd And so transformed from his former skill, That me he knew not, nether his owne ill; Till through wise handling and faire gouernaunce, I him recured to a better will, Purged from drugs of fowle intemperaunce: Then meanes I gan deuise for his deliuerance. ${ }^{13}$

\footnotetext{
12 Edmund Spenser, The Faerie Queene, ed. A.C. Hamilton (Harlow: Pearson Education, 2007) Longman Annotated English Poets, II, 1, 51.

13 Spenser, The Faerie Queene, II, 1, 54.
} 
Acrasia allowed them to leave the bower, sending them on their way with a cup as a parting gift. When Mortdant stopped to drink from a spring, however, the mixture of the water and a charm lurking in the cup killed him instantaneously. Just as Amavia is about to describe her response to her lover's death, she succumbs to her presumably self-inflicted injuries. Guyon is left in tears. He buries the two bodies, and swears an oath committing himself and the infant son of Mortdant and Amavia to revenge: 'with dew rites and dolorous lament | The end of their sad Tragedie vptyde.'14 Even beyond this explicit reference to genre, the language of stage tragedy runs thickly through the episode: 'Pageants of Mens Miseries', 'Pitiful Spectacle' (repeated twice in one stanza). But whereas performativity typically arouses the poem's suspicion about disguised identity and feigned feeling, Spenser here insists on framing Guyon's heroic purpose through a theatrical encounter.

The tragedy which Guyon observes and within which Mortdant and Amavia suffer is explicitly postlapsarian. Their son's hands, which have become covered in his mother's blood, cannot be cleansed by the water that poisoned his father, an emblem of guilt's grip on even the most innocent child: 'His guiltie handes from bloody gore to cleene; | He washt them oft and oft, yet nought they beene | For all his washing cleaner. ${ }^{15}$ Although their story bears a resemblance to Adam and Eve's - the role of temptation, the shared demise of a couple-Mortdant and Amavia embody the fallen experience of sin, rather than its origin. This experience is ultimately self-inflicted, insofar as it proceeds from willful action. Mortdant chooses to leave Amavia for a campaign of heroic accomplishment and instead resigns himself to sexual servitude. Her own courageous efforts to rehabilitate him to a 'better will' succeed only in hastening both of their deaths. Even the infant Ruddymane's will leads him toward the 'cruell sport' of playing contentedly in Amavia's 'purple gore.16 In postlapsarian tragedy, choices made through thoughtful deliberation and with beneficent intent still result in grave consequences. The will exists, but it seems to be capable only of wrongdoing.

By situating the will, a faculty intuitively associated with personal freedom, within a structure of narrative necessity, Spenser replaces the ancient Greek theory of tragic hamartia through ignorance with a Pauline psychology of sin. In his letter to the Romans, Paul describes the weakness of his own will, which drives him to act against his better judgment, that is to say, to behave akrati-

\footnotetext{
14 Spenser, The Faerie Queene, II, 2, 1.

15 Spenser, The Faerie Queene, II, 2, 3.

16 Spenser, The Faerie Queene, II, 1, 40.
} 
cally: 'For I knowe, that in me, that is to say in my fleshe, dwelleth no good thyng. For to wyll, is present with me: but I fynde no meanes to perfourme that which is good. For the good that I woulde, do I not: But the evyll which I woulde not, that do I. ${ }^{17}$ Protestant theologians generally analyze the problem of akrasia by positing two distinct causes of action in the world. Humans in a postlapsarian condition can do nothing but evil; good can be accomplished only by God. As a consequence, the Lutheran doctrine of salvation by faith alone encourages believers to attribute good works to the action of divine will rather than to personal merit, and the Calvinist concepts of unconditional election and double predestination sever the sovereignty of grace from the contingency of human notions of justice. According to all of these teachings, the will resembles a diseased appendage: formerly integral to human health and happiness, distorted from its purpose, and now causing nothing but pain. Despite Erasmus's sympathy for many features of Protestant theology, his commitment to a robust notion of free will, as evidenced in his debates with Luther on the topic between 1524 and 1526 , kept him aligned with Roman Catholicism.

What we now know as the Protestant ethic is a highly counter-intuitive historical consequence of this theology of the will. How could religious teachings that detach effort from reward give rise to such a prodigious model of labor and self-regulation as Benjamin Franklin? According to Max Weber's account of the relationship between doctrine and behavior, the transformation of good works from a cause of salvation to a sign or consequence thereof, a transformation which even some Protestants feared would lead to lawlessness, actually enhanced adherents' moral diligence:

however useless good works might be as a means of attaining salvation, for even the elect remain beings of the flesh, and everything they do falls infinitely short of divine standards, nevertheless, they are indispensable as a sign of election [...]. Thus the Calvinist, as it is sometimes put, himself creates his own salvation, or, as would be more correct, the conviction of it. But this creation cannot, as in Catholicism, consist in a gradual accumulation of individual good works to one's credit, but rather in a systematic self-control which at every moment stands before the inexorable alternative, chosen or damned. ${ }^{18}$

17 Romans 7:18-19, The Bishops' Bible.

18 Max Weber, The Protestant Ethic and the Spirit of Capitalism, transl. Talcott Parsons (New York: Scribner, 1958), p. 115 . 
It is the belief in the will's weakness, in its inability to choose rightly, therefore, that strengthens willpower. When choice is removed from an immediate chain of intention and consequence and re-inscribed within an abiding spiritual condition, the will can achieve remarkable consistency, because even a single lapse seems to indicate permanent damnation. The experience of life as a series of independent occasions to decide gives way to a sense that each and every choice reflects whether or not one has been chosen in turn.

If Spenser's purpose is to explore this theological terrain, then why does he choose Acrasia as the name of Guyon's sworn enemy, rather than something like Sin? Why would the poet go back to a concept derived from ancient Greek moral philosophy, when he had relevant Christian terminology at his disposal? Although some readers of The Faerie Queene have argued that, because temperance can be practiced outside of the framework of religion, Book II should be understood as an appraisal of a natural rather than a God-given virtue, the postlapsarian tragedy with which Guyon's narrative begins indicates that theology is by no means irrelevant to Spenser's formulation of his subject. ${ }^{19}$ Nevertheless, prior to these questions of allegorical significance come more practical matters of literary construction. In a poem that purports to provide moral instruction to its readers- 'The generall end therefore of all the booke is to fashion a gentleman or noble person in vertuous and gentle discipline', Spenser writes to Sir Walter Raleigh — the doctrine of the will's depravity offers little hope for any didactic project, let alone material for narrative interest. ${ }^{20}$ Right action is either a human impossibility or a kind of invariable compulsion; it certainly cannot be taught or learned. By setting Acrasia rather than Sin in Guyon's path, however, Spenser is able to give the will a purpose, if not within the soul, then at least within the story. She is a quintessential figure of romance, a witch in the tradition of Circe, Calypso, and the Sirens from The Odyssey, distracting men from their pursuit of epic goals with sexual temptation. For Homer, at least some of the men who fall victim to such temptation are capable of being redeemed. Odysseus in particular has a talent for enjoying pleasurable lures without being ensnared by them, relying on both external aids (the ropes that bind him to the mast of his ship, permitting him to listen to the Sirens' song without losing his life) and internal faculties (the will that allows him to forsake immortality with Calypso in favor of old age with Penelope) to preserve himself. By locating Acrasia in this lineage of romance temptresses, Spenser makes Guyon's resistance,

\footnotetext{
19 A.S.P. Woodhouse, 'Nature and Grace in The Faerie Queene', English Literary History 16 (1949), pp. 194-228, esp. p. 204.

$20 \quad$ Spenser, The Faerie Queene, p. 714.
} 
which has the total consistency characteristic of the Protestant ethic and which critics, therefore, have often considered fanatical, seem purposeful and heroic. Moreover, Acrasia's lack of a formal theological identity allows Verdant, one of the poem's many surrogates for Spenser's ideal didactic subject-young, aristocratic, Protestant, and male - to be rescued from her by Guyon. Had Verdant been trapped in Sin's clutches instead, his redemption would have been difficult to justify within the poem's religious framework, and tragedy would have been the governing genre of Book II, rather than an object of its scrutiny.

Romance does not replace tragedy, however, as Book II's definitive mode. The genres compete with one another until-and perhaps throughout - the climactic final canto. The episode with Amavia and Mortdant establishes Guyon's motives for defeating Acrasia as vengeful and, therefore, potentially tragic. But readers discover in the next canto that, as a knight of the Order of Maidenhead, he had already been ordered by Gloriana, his queen, to put a stop to Acrasia's activities before his fateful encounter with the wretched couple: 'My Soueraine, $\mid[\ldots]$ Me all vnfitt for so great purpose she employes.'21 The disclosure of these prior motives ensures that Guyon's narrative proceeds in an over-determined fashion, at once a chivalric quest and a revenge tragedy. The competition only intensifies as he approaches the Bower of Bliss, a romance space that has nevertheless given rise to the tragic consequences suffered by Amavia and Mortdant. At the entrance to the bower is a delicately wrought gate displaying the story of Medea, a hinge figure who links the motif of the attractive witch (Circe is her aunt) to akratic tragedy in the tradition of Euripides:

Yt framed was of precious yvory,

That seemd a worke of admirable witt;

And therein all the famous history

Of Iason and Medaea was ywritt,

Her mighty charmes, her furious louing fitt,

His goodly conquest of the golden fleece,

His falsed fayth, and loue too lightly flitt,

The wondred Argo, which in venturous peece

First through the Euxine seas bore all the flowr of Greece.

Ye might haue seene the frothy billowes fry

Vnder the ship, as thorough them she went,

21 Spenser, The Faerie Queene, II, 2, 43. 
That seemd the waues were into yuory,

Or yuory into the waues were sent;

And otherwhere the snowy substaunce sprent

With vermell, like the boyes blood therein shed,

A piteous spectacle did represent,

And otherwhiles with gold besprinkeled;

Yt seemd thenchaunted flame, which did Creusa wed. ${ }^{22}$

Spenser is not the first poet to posit an explicit affiliation between Medea and akrasia. In Book VII of Ovid's Metamorphoses, she offers up a sort of slogan for all those who tend to act against their better judgment: 'video meliora proboque, | deteriora sequor', which Arthur Golding renders with the gorgeous fourteener, 'The best I see and like: the worst I follow head-long still. ${ }^{23}$ Spenser's ekphrasis serves a broad intertextual purpose, invoking the Medea of ancient tragedy and episodic romance as a precedent for Acrasia, but the gate also communicates something to the characters within the poem. This story should serve as a clear warning to potential followers of Acrasia about the dangers of what lies inside the gate. Even those viewers who do not recognize the relevant iconography - the golden fleece, the Argonauts, the murdered childrenshould be put off by the fact that the image appears to be covered with blood. Yet, as is typical of Spenser's characters' encounters with symbolically laden works of art, very little of the obvious relevance of Medea's story seems to register within the poem. ${ }^{24}$ The narrator is more preoccupied with the image's impressive workmanship - the play between the form of the waves and their ivory matter-than with its moral lesson. The violence becomes aestheticized and abstracted: the magical fire which Medea used to burn Jason's new wife is transmuted into a golden decorative motif, and the field of red, meant to portray the blood Medea has spilt, is perceived only to be 'like' blood. At the level of

22 Spenser, The Faerie Queene, II, 12, 44-45.

23 Ovid, Metamorphoses, viI, 20-21 (transl. Frank Justus Miller) and Arthur Golding, Shakespeare's Ovid Being Arthur Golding's Translation of the Metamorphoses, ed. W.H.D. Rouse (Carbondale: Southern Illinois University Press, 1961), viI, 25.

24 Jeff Dolven has shown how Britomart, the knight of chastity, gazes upon a series of tapestries depicting sexual violence, not with an understanding of their relevance to her chosen virtue, but rather with a 'combination of avid spectatorship and incomprehension.' Her unresponsiveness - an unwillingness or an inability to pick up on the cues that have been set before her-allows her to cut herself 'free from the narrator, from Spenser, and from the teaching poem that hosts her.' See Jeff Dolven, Scenes of Instruction in Renaissance Romance (Chicago: University of Chicago Press, 2007), pp. 165-171, esp. p. 168 and p. 171. 
action and behavior within the narrative, the critical point is this: by encountering the story of Medea and then passing through the gate, Acrasia's victims are themselves acting against their better judgment. Like Medea, they know they are choosing badly: the best they see and like, the worst they follow headlong still.

Guyon's decision to pass through the gate, however, does not implicate him in akrasia: he has seen its tragic victims face to face, and his forward progress continues to be motivated by both a sense of chivalric duty and a vengeful purpose. Temptation does not take root in his imagination, although he does over the course of Book II find various objects and persons-enormous piles of gold, two charming nymphs-momentarily attractive. His response is to wonder at and even admire what he observes, but to keep himself detached from these feelings: 'Much wondred Guyon at the fayre aspect | Of that sweet place, yet suffred no delight $\mid$ To sincke into his sense, nor mind affect. ${ }^{25}$ His will remains in control, even of itself: 'Brydling his will, and maystering his might.'26 Verdant, by contrast, has given himself over to temptation entirely:

His warlike Arms, the ydle instruments

Of sleeping praise, were hong vpon a tree,

And his braue shield, full of old moniments,

Was fowly ra'st, that none the signes might see,

Ne for them, ne for honour cared hee,

Ne ought, that did to his aduancement tend,

But in lewd loues, and wastfull luxuree,

His dayes, his goods, his bodie he did spend:

O horrible enchantment, that him so did blend. ${ }^{27}$

He has lost every attribute of reflexive regulation — self-awareness, self-possession, and self-control — and abandoned every external source of his integritythe physical support of his weapons, as well as the cultural models formerly inscribed on his shield. Bliss is a dangerous state, because it converts time into money and then into even more precious substances: an interlude that is initially measured in 'dayes' soon takes hold of 'his goods, his bodie.' Although Book II avoids the theological terminology of sin, it is clear that Verdant's soul comes next in the sequence, as a temporary lapse threatens to shift over into a permanent condition. Acrasia seems perfectly aware of the tragedy she is about

\footnotetext{
25 Spenser, The Faerie Queene, II, 12, 53.

26 Spenser, The Faerie Queene, II, 12, 53.

27 Spenser, The Faerie Queene, II, 12, 79.
} 
to inflict. Even as she looms over him in a sinister fashion, she experiences the Aristotelian affect of pity in anticipation of her lover's fate: 'she sighed soft, as if his case she rewd. ${ }^{28}$ This eruption of tender concern, strange in so intractable a moral antagonist, is actually of a piece with her allegorical identity. Acrasia does not represent unadulterated evil; she regrets what she is about to do to Verdant, and she is prepared to go through with it nevertheless.

Just as Verdant's own generic ambivalence is about to resolve in favor of the tragic, Guyon succeeds in pulling him back into romance. Acrasia is trapped, Verdant redeemed, the bower destroyed:

But all those pleasaunt bowres and Pallace braue,

Guyon broke downe, with rigour pittilesse;

Ne ought their goodly workmanship might saue

Them from the tempest of his wrathfulnesse,

But that their blisse he turn'd to balefulnesse:

Their groues he feld, their gardins did deface,

Their arbers spoyle, their Cabinets suppresse,

Their banket houses burne, their buildings race,

And of the fayrest late, now made the fowlest place. ${ }^{29}$

Guyon's conduct at this moment has generated the poem's most famous crux. What can it mean for the knight of temperance to act so intemperately, to display such extreme behaviors as 'rigour' and 'wrathfulnesse'? To the rich discussion that has developed around this question, I will add only the following: Guyon's destruction of the bower means that his narrative remains suspended between tragedy and romance. His rage against beautiful buildings and gardens seems slightly unhinged, because it is completely extraneous to his chivalric intention, which is fulfilled at the moment of Acrasia's capture and Verdant's emancipation. The iconoclastic gesture pushes Guyon back into the territory of revenge tragedy: excessive, personally-motivated violence.

Moreover, in his effort to eradicate the bower, Guyon displays a deep-seated resistance to the contingencies of romance. He wants to eliminate even temporary pleasurable distraction, to perfect the will by destroying temptation. After Odysseus successfully resists Circe and saves the men she had transformed into swine, he remains in her company for an extended term of rest and recuperation: 'So there day after day for a full year we sat, feasting on abundant flesh and

28 Spenser, The Faerie Queene, II, 12, 73.

29 Spenser, The Faerie Queene, II, 12, 83. 
sweet wine. ${ }^{30}$ Guyon not only refuses to spend any more time in the bower, but also cannot accept its ongoing existence. In this sense, he resembles Aristotle, who acknowledges the existence of akrasia and then does everything in his power to exclude it from his philosophy. Guyon has already witnessed one non-Aristotelian tragedy; he cannot accept any more.

Spenser was known among friends for his serious interest in ancient Greek moral philosophy. Lodowick Bryskett, whose own studies in the field had been encouraged by Spenser, once tried to engage him on the topic at a social gathering, asking that he might 'open unto us the goodly cabinet, in which this excellent treasure of vertues lieth locked up from the vulgar sort.' ${ }^{31}$ Spenser demurred, but not because he objected to the request. He simply wanted his friends to wait for The Faerie Queene, which would satisfy their desire for an Aristotelianism accessible to a vernacular audience. As he explained, the whole poem was designed with Bryskett's purpose in mind:

to represent all the moral vertues, assigning to every vertue, a Knight to be the patron and defender of the same: in whose actions and feates of armes and chivalry, the operations of that vertue, whereof he is the protector, are to be expressed, and the vices \& unruly appetites that oppose themselves against the same, to be beaten downe and overcome. ${ }^{32}$

In transforming moral philosophy into narrative, in adapting ancient virtues for a Protestant nation, Spenser discovered a place for akrasia within a system that originally excluded it. In so doing, he also helped to forge a tense, yet fruitful alliance between romance's intermediacy and tragedy's concern with permanence and ends.

\section{Shakespearean Akrasia: Temporary Evil on Stage}

Spenser's explicit engagement with akrasia and narrative structure should be understood as part of a broader interest in the relationship between temptation and temporality among English Renaissance writers. Some dramatists chose to pursue this interest through a version of festive comedy, where a set period for license makes wrongdoing more or less permissible. Ben Jonson's The

\footnotetext{
$30 \quad$ Homer, The Odyssey, $\mathrm{x}, 467-468$ (transl. A.T. Murray).

31 Lodowick Bryskett, A Discourse of Civill Life (London: William Aspley, 16o6), p. 26.

32 Bryskett, A Discourse of Civill Life, p. 27.
} 
Alchemist, for example, centers on three characters who lie, cheat, and steal with impunity and great verve while most citizens are away from home during a season of plague. When Lovewit, the master of the house, returns to the city, he looks on what has happened with indulgence, even as he restores order and hierarchy. The transformation of Prince Hal into Henry v, of a wastrel into a king, makes temporary festivity an integral part of strategic self-fashioning. When Hal's extended adolescence (so like and then suddenly so unlike Falstaff's) comes to an end, it is as if sovereignty has taken possession of his whole being. When he speaks to Falstaff, he denies their long friendship as if it were a nightmare from which he has been roused once and for all: 'I have long dreamt of such a kind of man, | So surfeit-swelled, so old, and so profane; | But being awaked, I do despise my dream. ${ }^{33}$

Even when kept within strict temporal bounds, however, akrasia was more often treated as a tragic phenomenon. In Paradise Lost, John Milton posited intentional wrongdoing as the origin of mortality and, therefore, of temporariness as the condition of life itself. As Adam and Eve's story veers toward akrasia, the poet 'must change | Those Notes to Tragic.' ${ }^{34}$ In Doctor Faustus, Christopher Marlowe probed the Protestant theology that Spenser only brushed up against, making the state of tending to act against one's better judgment explicitly a matter of sin. Faustus's scholarly profession ensures that the relationship between knowledge and akrasia is more pronounced for him than it is for Guyon, whose intellect lacks any remarkable distinction. The will, however, persists as the primary faculty through which wrongdoing can be either undertaken or resisted. A decision that seems to commit Faustus to evil only for the medium term, that he can cancel at any moment simply by repenting, comes to feel irrevocable.

I will end with a brief consideration of Shakespeare's Macbeth, which takes the unresolved tension between romance and tragedy that animates Spenser's engagement with akrasia and creates a more integrated whole. Guyon's generic indeterminacy - his suspension between vengeful and chivalric motivationsnever compels him to act against his better judgment. Macbeth's experience of akrasia is more intimate and thoroughgoing: he wants to move beyond wrongdoing, but only by passing through it. The play's fundamental problem is how to get from here to there, from where one is at present to where one wants to be, from a prophecy to its fulfillment. Temporariness is both the

\footnotetext{
33 Shakespeare, Henry IV, Part 2, ed. René Weis (Oxford and New York: Oxford University Press, 1997) The Oxford Shakespeare, 5.5.48-50.

34 John Milton, Paradise Lost, ed. Alastair Fowler (Harlow: Pearson Education, 2007), Longman Annotated English Poets, IX, 5-6.
} 
problem — how can Macbeth embark on a course he knows to be evil—and the apparent solution-his crimes will come to an end once he has become king. But temporariness turns out to be a more demanding state than he bargains for, and the intrinsic insecurity of Macbeth's position, lacking an heir but plagued by rivals, pushes him to persist in wrongdoing long after he expected to abandon it. Initially, he acknowledges the evil of his actions, but he remains certain that he will be able to change. In the end, however, he cannot accept the fact that he has destroyed his soul for such an unstable, impermanent achievement. Temporariness, Macbeth's original justification, gives way to a desperate - and futile - effort to endure.

From the opening scene, the witches establish the medium term of romance at the center of the play's tragic design. The first four lines demonstrate the sisters' control over the boundaries of an action, both its beginning and its end, and their attribution of the intermediate phase to men:

$\begin{array}{ll}1 \text { WITCH } & \text { When shall we three meet again? } \\ \text { In thunder, lightning, or in rain? } \\ 2 \text { WITCH }\end{array}$

Their knowledge of origins and consequences, of the current situation and its eventual outcome, sets up the prophecy's fundamental division of temporal labor, according to which Macbeth must act in order to transport himself from where he is to where the witches have promised he will be: 'All hail Macbeth! that shalt be king hereafter. ${ }^{36}$

Both Macbeth and Lady Macbeth see intermediacy as a problem which vigorous agency might solve. He has no trouble acknowledging what his 'Vaulting ambition' wants to happen, but his will lacks the sheer forcefulness it needs to proceed: 'I have no spur | To prick the sides of my intent.' ${ }^{37}$ She has will enough to spare, so much in fact that she can feel 'The future in the instant', imagining each intervening barrier giving way to her desire. ${ }^{38}$ The witches, however, reject this model of action along a forward trajectory. They imagine intermediacy, not in terms of epic purpose, but rather in terms of romance contingency:

35 Shakespeare, Macbeth, ed. Kenneth Muir (London: Methuen, 1984) The Arden Shakespeare, 1.1.1-4.

36 Shakespeare, Macbeth, 1.3.50.

37 Shakespeare, Macbeth, 1.7.25-27.

38 Shakespeare, Macbeth, 1.5.58. 
'Though his bark cannot be lost, | Yet it shall be tempest-tost.'39 The certainty of the outcome does not guarantee the directness of the route.

Indeed, once Macbeth finds himself in the midst of this tempest, once the initial bout of murderousness has given way to a precarious hold on the throne, the experience of temporariness becomes a huge existential burden. The same prophecy that predicts his ascension to the throne also promises Banquo a line of royal offspring, so Macbeth begins to fret over his own natal legacy. (Up until Act III, the most notable reference to Macbeth's offspring is Lady Macbeth's hypothetical offer to crush her infant's skull.) As Luke Wilson has brilliantly argued, Macbeth's anxiety about paternity is related to a fear of cuckoldry: 'the murder of Duncan as his own (one might say sexual) defilement [...], a defilement however that has paradoxically resulted in offspring that are not his own, but which he nevertheless finds himself providing for as if they were. 40 Even more troubling to Macbeth than the sexual entanglement, however, is its temporal logic: he has sacrificed his immortal soul ('mine eternal jewel | Given to the common Enemy of man') without securing a worldly future for himself through his children. ${ }^{41}$ The permanence of damnation compels him to search for an analogous form of stability across earthly time. When hired assassins fail to kill Banquo's son, Fleance, Macbeth can hardly endure the thought that his efforts to secure the future have failed. Temporariness has come to feel like a trap: 'But now, I am cabin'd, cribb'd, confin'd, bound in | To saucy doubts and fears. ${ }^{42}$

Macbeth eventually recognizes that, as a mortal being, he cannot escape from his temporary condition: 'I have liv'd long enough: my way of life | Is fall'n into the sere, the yellow leaf. 43 But his acceptance of his own boundedness does not open him up to the contingencies of romance. Instead, he pursues epic action more single-mindedly than ever: 'I'll fight, till from my bones my flesh be hack'd.44 His last words before he dies at the hands of Macduff curse the man who yields to another, the man who gives up his will to act, no matter how futile the effort: 'And damn'd be him that first cries, 'Hold, enough!' 45

\footnotetext{
39 Shakespeare, Macbeth, 1.3.24-25.

40 Luke Wilson, 'Macbeth and the Contingency of Future Persons', Shakespeare Studies 40 (2012), pp. 53-62, esp. p. 59 .

41 Shakespeare, Macbeth, 3.1.67-68.

42 Shakespeare, Macbeth, 3.4.23-24.

43 Shakespeare, Macbeth, 5.3.22-23.

44 Shakespeare, Macbeth, 5.3.32.

45 Shakespeare, Macbeth, 5.8.34.
} 
Readers of Shakespeare have long noticed the way in which his late romances-The Winter's Tale, most notably—borrow from tragedy. Cruelty and death are redeemed, belatedly and incompletely, through a series of fantastical interventions. The brief literary history of akrasia I have traced shows that the influence also runs in the other direction, that English Renaissance tragedies borrow from romance. Medea, marginalized in Aristotelian tragic theory, brings knowing evil to the center of the early modern genre. In so doing, however, she and her consort witches shift from protagonists to tempters, the roles they typically occupy in romance. They draw in their victims with the promise that wrongdoing might be restricted to the medium term, that sin might be enjoyed for a time and then brought successfully to an end. Such a promise offers an alternative to various Protestant teachings about the will's depravity, on the one hand, and its fanatical consistency, on the other. But the experience of temporary evil, so bracing in the imagination, proves to be unbearable, leading to the total dissolution of Verdant, the frenetic violence of Guyon and Macbeth, the suicide of Lady Macbeth, the despair of Faustus, and the very mortality of Adam and Eve.

\section{Further Reading}

Ainslie, George, Breakdown of Will (Cambridge and New York: Cambridge University Press, 2001).

Eden, Kathy, 'Aristotle's Poetics: A Defense of Tragic Fiction', in Rebecca Bushnell (ed), A Companion to Tragedy (Malden, MA: Blackwell Publishing, 2005), pp. 41-50.

Lorenz, Hendrik, 'Aristotle's Analysis of Akratic Action', in Ronald Polansky (ed), The Cambridge Companion to Aristotle's Nicomachean Ethics (New York: Cambridge University Press, 2014), pp. 242-262.

North, Helen, Sophrosyne:Self-Knowledge and Self-Restraint in Greek Literature (Ithaca: Cornell University Press, 1966) Cornell Studies in Classical Philology, 35.

Saarinen, Risto, Weakness of the Will in Renaissance and Reformation Thought (Oxford: Oxford University Press, 2011).

Vernant, Jean-Pierre, 'Intimations of the Will in Greek Tragedy', in Jean-Pierre Vernant and Pierre Vidal-Naquet, Myth and Tragedy in Ancient Greece, transl. Janet Lloyd (New York: Zone, 1990), pp. 49-84.

Weber, Max, The Protestant Ethic and the Spirit of Capitalism, transl. Talcott Parsons (New York: Scribner, 1958). 